\title{
Operationalising Community Resilience to Climate Change in Developing Countries: A Grounded Delphi Method (GDM) Approach
}

Alima Ogah ( $\square$ alima2015@gmail.com )

Teesside University https://orcid.org/0000-0002-5669-4625

Tracey Crosbie

Teesside University

Theresia Komang Ralebitso-Senior

Liverpool John Moores University

\section{Research Article}

Keywords: Community resilience, climate change, policies, coping capacity, adaptive capacity

Posted Date: September 9th, 2021

DOl: https://doi.org/10.21203/rs.3.rs-844800/v1

License: (c) (i) This work is licensed under a Creative Commons Attribution 4.0 International License.

Read Full License 


\section{Abstract \\ Background}

Climate change and its impact have taken centre stage in contemporary political economic discourse. Climate change is posing complex problems that far outweighs the solutions suggested by the conventional analytical tools used for guiding responses to major environmental challenges. This is particularly the case in developing countries like Nigeria. Unsurprisingly the concept of community resilience towards climate change has received a great deal of attention from researchers and policy makers. However, community resilience is a contested concept, which leads to disagreement about the methods of achieving it. The nature of community resilience makes the measurement of the efficiency of the policies designed to increase community resilience problematic, particularly in developing countries where limited funds must be prioritised.

\section{Methods}

The research presented uses a Grounded Delphi Method (GDM) to identify how experts in Nigeria define community resilience and reach a consensus on its measurement in Nigeria's context and other developing nations. The data collection involved three rounds of Delphi with a panel of 21 experts, the first round employed semi-structured interviews, following the exploratory Delphi approach, and subsequent rounds employed online surveys.

\section{Findings:}

The findings indicate that there is a process of stages that communities need to go through to become resilient to climate change. These begin with coping with climate change, followed by adaptation to climate change with the final stage being transformation in the face of climate change. Twenty indicators are identified categorised under eight elements that are suitable for measuring community resilience at the different stages of this process. It is interesting to note that the experts in Nigeria who participated in the study excluded notions of transformation in their conceptualisation of community resilience illustrating a potential gap in their perceptions of the requirements for how communities can become fully resilient.

\section{Conclusion}

This research provides a method of prioritising specific, measurable indicators to inform policies designed to reduce the impacts of climate change by supporting community resilience in the context of developing countries with limited funding. 


\section{Introduction}

Climate change events such as heavy rainfall, floods, storms, drought and heat waves are affecting many parts of the world. The impact of any given shock at the community level depends on the magnitude of the hazard, the community's vulnerability to that shock and their capacity to withstand it. For most catastrophic cases, a shock can completely overwhelm a community to the point of collapse. Ultimately, the impacts of climate change vary according to geographical locations as some regions are affected more negatively than others (Wood et al. 2014; Tolentino-Arevalo et al. 2019). Also, the impacts of climate change at the community level are linked to vulnerability to shock and resilience capacity of the affected individuals (Proag, 2014; Tambo, 2016; Ullah et al. 2021).

The concept of community resilience has been increasingly discussed in academic and policy domains (Steiner et al. 2016; Abramson et al. 2015; Summers et al. 2017; Cutter, 2020). Many governments, policy makers and industry stakeholders have designed policies to support community resilience (Campos et al. 2017; Pietrapertosa et al. 2017), and proposed actions that mitigate, or facilitate adaptations to deal with, the negative impacts of climate change on communities (Barua et al. 2014; Gillard et al. 2017). Despite the numerous available sources of literature on community resilience (Patel et al., 2017; Summers et al. 2017; Ogah, 2021), the concept is still challenging and evolving (Tanner et al. 2017; Manyena et al. 2019), and is subject to different interpretations and definitions (Berbes-Blaquez et al. 2017; Doorn, 2017; Patel et al. 2017). The diverse definitions pose epistemological and methodological issues when seeking to operationalise the concept in policy and research (Manyena et al. 2019). With no clear definition of community resilience policy makers have no clear methods for its assessment. If we cannot define and measure community resilience, how can we learn from the impact of policies and understand what is working and what is not? Without measurement and study there is no learning and without learning there is no forward progress other than that which might occur accidentally. To address this gap for policies aiming to increase resilience in the face of climate change, this research paper illustrates how community resilience can be defined and measured in the context of Nigeria. The approach adopted is also relevant to other developing countries with similar social, economic and demographic contexts.

The remainder of this paper is divided into five sections. Following this introduction, section two presents an overview of earlier attempts to define and measure community resilience. Section three outlines the research methodology used. Section four presents the results, section five discusses the significance of the research findings and section six concludes the paper.

\section{Earlier Attempts To Define And Measure Community Resilience}

Ogah (2021) conducted a systematic review which identified the three main ways in which community resilience is defined in the literature published between 2007 and 2018. These are coping capacity, adaptive capacity and transformative capacity. Coping capacity refers to the short-term ability of a community to cope with the impact of climate change (Ogah 2021). Community resilience as adaptive capacity is associated with long-term timeframes and implies that some learning or change in condition 
occurs which enables a community to become resilient. Transformative capacity is the capacity of a social, economic and environmental system to cope with a hazardous event or trend or disturbance, responding or reorganising in ways that maintain their essential function, identity and structure, while retaining the capacity for adaptation, learning and transformation (Jacobs and Cramer, 2017, pp.1). Transformative capacity is associated with changes in the deep structures that lead to vulnerability and risk, as well as the root causes of the issues. These definitions of community resilience are based on the stages and process which a community needs to go through to become resilient. This paper, therefore, explores how community resilience is defined by government experts involved in climate change policy process in Nigeria, to understand the process they follow and the stage which they are in towards becoming resilient.

Ogah (2021) identified 49 indicators (Table 1) under eight elements (social, economic, demographic, infrastructure, institutional, environmental, training and awareness, health and fatality). The most frequently used elements for measuring community resilience were the social, economic and infrastructural and the least used were environmental, training and awareness and health and fatality. The latter are particularly important in Nigeria and other developing countries, due to their geographical area, land characteristics, coastal locations, high natural climate variability, highly vulnerable population, and limited finance and technological capacity to adapt to climate change (IPCC, 2014; Akanwa and JoeIkechebelu, 2018). 
Table 1

Elements and indicators of community resilience capacities (Ogah, 2021)

\begin{tabular}{|c|c|c|}
\hline Capacities & Elements & Review Indicators \\
\hline \multirow[t]{20}{*}{ Coping capacity } & \multirow[t]{3}{*}{ Social } & Attachment to place \\
\hline & & Collective knowledge and experience \\
\hline & & Inter-community relationship \\
\hline & \multirow[t]{2}{*}{ Economic } & Annual income \\
\hline & & Home ownership \\
\hline & \multirow[t]{5}{*}{ Demographic } & Age \\
\hline & & Sex \\
\hline & & Educational attainment \\
\hline & & Household size \\
\hline & & Religious adherence \\
\hline & \multirow[t]{2}{*}{ Infrastructural } & High speed communication \\
\hline & & Existence of evacuation route \\
\hline & Institutional & Volunteerism \\
\hline & \multirow[t]{2}{*}{ Environmental } & Mutual communication \\
\hline & & Improve green space and tree planting \\
\hline & \multirow[t]{5}{*}{ Health and fatality } & Access to health care assistance a facility \\
\hline & & Sanitation and infection control \\
\hline & & Nutritional status \\
\hline & & $\begin{array}{l}\text { Access to special needs and psychological } \\
\text { support }\end{array}$ \\
\hline & & Date rate \\
\hline \multirow[t]{6}{*}{ Adaptive capacity } & \multirow[t]{3}{*}{ Social } & Social trust \\
\hline & & Community engagement \\
\hline & & Relationship with other stakeholders \\
\hline & \multirow[t]{3}{*}{ Economic } & More than one source of income \\
\hline & & household asset \\
\hline & & Access to credit \\
\hline
\end{tabular}




\begin{tabular}{|c|c|c|}
\hline Capacities & Elements & Review Indicators \\
\hline & & Insurance coverage \\
\hline & & Ecological fund \\
\hline & \multirow[t]{4}{*}{ Infrastructural } & Relocation camps available \\
\hline & & Disaster resilient infrastructure \\
\hline & & Disaster management base \\
\hline & & Domestic and industrial waste facilities \\
\hline & \multirow[t]{3}{*}{ Institutional } & Land use planning \\
\hline & & Responsibility distribution \\
\hline & & Partnership between sectors \\
\hline & \multirow{3}{*}{$\begin{array}{l}\text { Training and } \\
\text { awareness }\end{array}$} & Learning and awareness \\
\hline & & Information dissemination \\
\hline & & Resource monitoring and feedback mechanism \\
\hline & \multirow[t]{4}{*}{ Environmental } & Renewable energy \\
\hline & & Conservation of biodiversity \\
\hline & & Agricultural practices \\
\hline & & Land remediation \\
\hline \multirow{5}{*}{$\begin{array}{l}\text { Transformative } \\
\text { capacity }\end{array}$} & \multirow[t]{2}{*}{ Institutional } & Mitigation plan \\
\hline & & Accident planning \\
\hline & \multirow[t]{3}{*}{ Infrastructural } & Access to water \\
\hline & & Access to electricity \\
\hline & & Transportation \\
\hline
\end{tabular}

Since all elements are interlinked, increasing the positive indicators in only one or few elements will hinder the overall resilience of a community as the omitted components might create new vulnerability and impact on a community's resilience (Constas et al. 2014; Quinlan et al. 2015). Therefore, and although this might not be possible due to institutional and financial limitations, policy should seek to increase the indicators levels for each element (Islam and Walkerden 2017). Therefore, policymakers need to prioritise some elements and their indicators depending on specific situation in addressing an impact (Engle et al. 2013). Given the need for prioritisation, our research seeks to understand how policies 
designed to increase community resilience in Nigeria can be prioritised as a case study for developing nations.

\section{Methodology}

A Grounded Delphi Method (GDM) which incorporates features of Grounded Theory and Delphi is superior to the traditional Delphi approach as it "improves the rigour of theory building in Delphi studies, while the consensus, or force ranking, aspect of Delphi assists in improving the relevant level of importance of categories derived from Grounded Theory" (Howard, 2018, pp. 6). In Grounded Theory, the theory should emerge rather than be built (Okoli and Pawlowski, 2004). Expert selection is key to the success of research employing the Delphi method as participants are highly relevant to the questions asked, which ensures their interest throughout the Delphi process (Donohoe, 2011).

Following previous research (Donohoe 2011; Päivärinta et al. 2011; Howard 2018), we selected expert panel members based on the following criteria: knowledge and experience of the study field; more than five years of working experience in the area of interest; ability and willingness to participate; adequate time to participate; and effective communication skills. Experts were contacted using electronic communication of e-mail and telephone calls to explain the purpose of the study. Snowball sampling - a type of purposive sampling where further participants are obtained from the existing participants (Cloke et al. 2004; Taherdoost, 2016) - ensured that the experts met the pre-determined definition of expertise. A panel of 21 experts was assembled where six are employed at the regional and state level while the remainder are employed at the national level of the Nigerian government. Since the retention rate was excellent, with only one dropout, the final expert panel consisted of 20 respondents that completed three rounds of the Delphi study. Most panellists were employed by the Nigeria's Department of Climate Change or the Ministry of Environment. They have between five and forty years of work experience in areas related to the climate change policy process and hold a $\mathrm{PhD}$, masters or undergraduate degree.

Following the exploratory Delphi approach the data collection began by conducting a semi-structured interview with each member of the expert panel. The interviews, conducted between March to April 2019, lasted between thirty minutes and one hour. They were designed to understand how the members of the expert panel defined community resilience and the indicators they thought might be used to measure levels of community resilience in the context of Nigeria. The interviews were audio-recorded, transcribed and analysed manually using open coding.

A further two rounds of Delphi were conducted using online surveys to reach a consensus between experts on how competing issues can be prioritised to improve community resilience in developing countries. These were used to assess a list of pre-defined indicators from the Delphi for measuring community resilience to climate change. Respondents gave answers using a 5-point Likert-type scale which allows for a degree of opinion in responses, and therefore, quantitative data can be obtained (Asun et al. 2016; Bryman, 2016). The criteria of checking the agreement rating of the impact assigned to the responses included: 5 very important; 4 important; 3 moderately important; 2 slightly important; and 1 
unimportant. The data were reviewed to remove errors and then analysed with Microsoft Excel. In measuring for consensus, the methods of standard deviation, weighted mean and interquartile range (IQR) were used as also recommended by Bailie (2011) and Habibi et al. (2014).

\section{Results}

\subsection{Delphi round one}

Of the experts interviewed 12 defined community resilience in terms of adaptive capacity (a situation characterised by flexibility), 5 defined the concept in terms of coping capacity (a process characterised by stability) and 4 defined it in terms of a combination of coping and adaptive capacity (Table 2). 
Table 2

Interviewees' definitions of community resilience

$\begin{array}{llll}\text { Category } & \begin{array}{l}\text { Scale of } \\ \text { influence }\end{array} & \text { Direct quote of community resilience definition } & \text { Experts }\end{array}$

Coping Community The ability of the community to bounce back after undergoing A capacity some climate-induced disaster.

The ability of a community to withstand shock or bounce back C from a climate change disaster that have occurred over a period of time.

The ability of the community to withstand shock or disaster or $\quad \mathrm{H}$ negative impact of climate change and to withstand such disaster.

The ability of a community to bounce back to its original state $\mathrm{N}$ after a climate change event.

Unspecific The concerted efforts to get results during an environment $\quad F$ issue.

Adaptive Community The capacity of community to cope or resist the risk to climate $E$ capacity change. Capacity to adapt to the impact of climate change.

The ability of an area or community to work against a particular problem. To put in place measures of combating a particular problem which may be affecting their communities.

The ability of the community to withstand the impact of climate change. How equipped the communities are to adapt to the impact of climate change.

The ability of the community to understand and be able to J guard themselves on the impact of climate change.

The ability of a particular community to withstand the severity $\mathrm{K}$ of the adverse impact of climate change. The capacity of the society to adjust and readjust to the adverse impact of climate change.

The ability of the community to put up adaptive measures in place against climate change.

The ability of the community to adjust and adapt to the impact $\quad M$ of climate change.

How the community can resist the impact of climate change? It just to make them take precautions, prepared and to plan for the impact of climate change.

The ability of a community to apply the available resources to $R$ adapt, respond to, withstand, and recover from adverse situations.

It means the ability of the community to utilise the available resources to respond to and respond to negative situations and disaster. 


\begin{tabular}{|c|c|c|c|}
\hline Category & $\begin{array}{l}\text { Scale of } \\
\text { influence }\end{array}$ & Direct quote of community resilience definition & Experts \\
\hline & & $\begin{array}{l}\text { Community resilience is the ability of communities to prepare } \\
\text { for anticipated hazards, adapt to changing conditions and } \\
\text { withstand and recover rapidly from disruption as a result of } \\
\text { climate change. }\end{array}$ & $\mathrm{T}$ \\
\hline & & $\begin{array}{l}\text { Community resilience is the sustained ability of a community } \\
\text { to utilise the available resources to respond to and recover from } \\
\text { adverse situations. }\end{array}$ & $\mathrm{U}$ \\
\hline \multirow{4}{*}{$\begin{array}{l}\text { Coping } \\
\text { and } \\
\text { adaptive } \\
\text { capacity }\end{array}$} & $\begin{array}{l}\text { People- } \\
\text { centred }\end{array}$ & How people are able to adapt or cope with climate change. & B \\
\hline & Community & $\begin{array}{l}\text { The way communities tend to guide against further disaster or } \\
\text { coping and adaptive strategies of communities to deal with } \\
\text { disaster. a feedback mechanism of the community to get back } \\
\text { to itself after a climate event. The ability of a community to } \\
\text { adjust or readjust themselves from prevailing situations or the } \\
\text { environmental problems they face. }\end{array}$ & D \\
\hline & & $\begin{array}{l}\text { The ability of the community to adapt to the impact of climate } \\
\text { change. Putting things in place to reduce the effect of climate } \\
\text { change on communities. How communities are able to cope } \\
\text { with the impact. }\end{array}$ & $\mathrm{P}$ \\
\hline & & $\begin{array}{l}\text { The ability of a community to adapt and cope during a disaster } \\
\text { and to return to its previous state. }\end{array}$ & Q \\
\hline
\end{tabular}

The questions asked during the interviews were based on how the experts understood community resilience and how it is measured Hence indicators which are relevant to measuring community resilience and reducing the impact of climate change were identified and subsequently categorised into the following eight elements: infrastructural; training and awareness; environmental; social; economic; demographic; institutional, and health and fatality (Table 3). Interviewees most frequently referred to infrastructural and training and awareness elements. 
Table 3

Elements and their indicators for measuring community resilience identified by the experts

\begin{tabular}{|c|c|c|}
\hline Elements & Indicators & No. of experts \\
\hline \multirow[t]{3}{*}{ Infrastructure } & Resilient infrastructure and maintenance & 15 \\
\hline & Adequate domestic and industrial waste facilities & 2 \\
\hline & Disaster management centre & 21 \\
\hline \multirow[t]{2}{*}{ Training and awareness } & Learning and awareness & 18 \\
\hline & Adequate resource monitoring and feedback mechanism & 5 \\
\hline \multirow[t]{2}{*}{ Environment } & Renewable energy & 6 \\
\hline & Sustainable agricultural practices & 17 \\
\hline \multirow[t]{2}{*}{ Social } & Community engagement and empowerment & 10 \\
\hline & Inter-community relationships & 2 \\
\hline \multirow[t]{3}{*}{ Economic } & Adequate livelihood & 9 \\
\hline & Access to credit & 1 \\
\hline & Ecological fund & 5 \\
\hline Demographic & Education & 9 \\
\hline \multirow[t]{3}{*}{ Institutions } & Enforcement of good land use planning & 3 \\
\hline & Equal distribution of responsibility & 7 \\
\hline & Synergy and harmonisation of policy & 3 \\
\hline Health and fatality & Access to health assistance and facilities & 4 \\
\hline
\end{tabular}

\subsubsection{Delphi Round Two (Survey)}

The indicators for measuring community resilience identified in round one of the Delphi study formed the basis of the survey conducted in round two of the Delphi study. The data from the survey was analysed based on the resulting Weighted Average (WA), Standard Deviation (SD) and Interquartile Range (IQR) as presented in Table 4. These different methods can be used to measure the importance of each indicator and achieve consensus (Murphy et al. 1998; Bailie, 2011). This method of weighting is acceptable for consensus (Hasson et al., 2000). Weighted average was used for understanding the experts opinions on the significance of the indicators (Greatorex and Dexter, 2000), hence their range from 3.75 to 4.65 shows that all the indicators were significant. In addition, these indicators were significant since more than $70 \%$ of experts were in agreement (Diamond et al. 2014; Slade et al. 2014; Musa et al. 2015). 
Table 4

Rating result by 20 experts of the importance of community resilience indicators round two

\begin{tabular}{|lllll|}
\hline Indicators & WA & SD & IQR & Rank \\
\hline Resilient infrastructure and maintenance & 4.65 & 0.93 & 0 & 1 \\
\hline Learning and awareness & 4.6 & 0.83 & 1 & 2 \\
\hline Educational status & 4.45 & 0.83 & 1 & 3 \\
\hline Adequate resource monitoring and feedback mechanisms & 4.45 & 0.69 & 1 & 3 \\
\hline Enforcement of good land use planning & 4.4 & 1.14 & 1 & 5 \\
\hline Community engagement and empowerment & 4.35 & 0.75 & 1 & 6 \\
\hline Sustainable agricultural practices & 4.35 & 0.75 & 1 & 6 \\
\hline Synergy and harmonisation of policy & 4.3 & 0.98 & 1 & 8 \\
\hline Adequate livelihood & 4.25 & 0.91 & 1 & 9 \\
\hline Ecological funding & 4.2 & 1.06 & 1 & 10 \\
\hline Inter-community relationships & 4.15 & 1.27 & 1 & 11 \\
\hline Adequate domestic and industrial waste facilities & 4.05 & 1.10 & 2 & 12 \\
\hline Disaster management centres & 4.05 & 1.00 & 1 & 12 \\
\hline Access to healthcare assistance and facilities & 4.05 & 1.19 & 1 & 12 \\
\hline Equal distribution of the responsibility & 4.05 & 0.95 & 1 & 12 \\
\hline Access to credit & 3.95 & 1.23 & 1.25 & 16 \\
\hline Renewable energy & 3.75 & 1.33 & 2.25 & 17 \\
\hline
\end{tabular}

Standard deviation and interquartile range are complimentary resulting in their combined use in previous studies (Musa et al. 2015). Standard deviation is used in measuring consensus (Holey et al. 2007) as it determines how far each response is from the weighted average (Rayens and Hahn, 2000). Standard deviation, which uses all the data in the survey, measures outliers and how far each observation is from the mean (Murphy et al. 1998; Rayens and Hahn, 2000). Furthermore, the standard deviation of the individual response to each indicator $(\geq 1)$ was calculated in this study. A standard deviation between 0 and 1 is considered a strong consensus while that more than 1 reflects a weak consensus (Goldman et al. 2008). The standard deviation analysis in this research shows that only $59 \%$ of the experts agreed, indicating that consensus was not reached among the expert group on the 17 indicators within Delphi two. As indicated in Table 4, the standard deviation analysis identified seven indicators for which there was no consensus as follows: Adequate domestic and industrial waste facilities ( $S D=1.10>1)$; Access to credit $(S D=1.23>1)$; Renewable energy $(S D=1.33>1)$; Enforcement of good land use planning $(S D=$ 
$1.14>1)$; Ecological funding ( $S D=1.06>1)$; Inter-community relationships $(S D=1.27>1)$; and Access to healthcare assistance and facilities $(S D=1.19>1)$.

The Interquartile range less than or equal to one $(<1$ or $=1)$ is considered as strong consensus whereas an IQR more than one (>1) is considered a weak consensus (Murphy et al. 1998). The IQR is very important as it is computed by using data lying along the first quartile (25\%) and the third quartile (75\%), and measures the mid-spread or the middle $50 \%$ of responses (Musa et al., 2015). Similar to the findings of the standard deviation, the IQR shows that there was no consensus for three out of the 17 community resilience indicators. These were adequate domestic and industrial waste facilities (IQR $=2>1)$; Access to credit (IQR = 1.25>1); and Renewable energy (IQR $2.25>1)$ (Table 4). The main purpose of using a Delphi method is achieving a significant level of consensus from the expert panel on each of the community resilience indicators, which this Delphi round failed to achieve.

While some researchers have recommended the use of interquartile range to measure consensus (Alshehri et al. 2015; Musa et al. 2015), the results of this research suggest not to rely on the technique wholly. The IQR gives a clear view of the overall data by removing the outlying values and by measuring the dispersion based on two values from the dataset (Giannarou and Zervas, 2014). However, the standard deviation is a more substantial measure of distribution as it considers every value in the data (Goula, 2013). Therefore, the use of the standard deviation method in the current research helps in investigating further the range of indicators where consensus is weak since the interquartile range technique may overlook those indicators.

\subsubsection{Delphi Round Three (Survey)}

In addition to the 17 community resilience indicators identified in round one of the Delphi study, the expert panel identified three more indicators as significant in round two. These are communicating information in local languages; the role of faith-based organisations; and exhibition programmes to showcase local produce. As a result, the final round (Delphi three) consisted of a rating of the 20 indicators by the 20member expert group using a 5-point Likert scale. In the analysis, the weighted average was between 4.10 to 4.70 showing that they were all important. Likewise, the standard deviation ranged from 0.47 to 0.99 , while the inter-quantile range were all $\leq 1$ indicating that consensus was reached on all 20 indicators (Tables 5 and 6). 
Table 5

Rating result by 20 experts of the importance of community resilience indicators round three

\begin{tabular}{|lllll|}
\hline Community Resilience Indicators & WA & SD & IQR & RANK \\
\hline Learning and awareness & 4.9 & 0.31 & 0 & 1 \\
\hline Communicating information in local languages & 4.85 & 0.37 & 0 & 2 \\
\hline Sustainable agricultural practices & 4.7 & 0.47 & 1 & 3 \\
\hline Access to healthcare assistance and facilities & 4.65 & 0.59 & 1 & 4 \\
\hline Synergy and harmonisation of policy & 4.55 & 0.6 & 1 & 5 \\
\hline Adequate resource monitoring and feedback mechanisms & 4.5 & 0.51 & 1 & 6 \\
\hline Ecological funding & 4.5 & 0.76 & 1 & 7 \\
\hline Adequate domestic and industrial waste facilities & 4.5 & 0.69 & 1 & 8 \\
\hline Enforcement of good land use planning & 4.5 & 0.69 & 1 & 9 \\
\hline Renewable energy & 4.45 & 0.94 & 1 & 10 \\
\hline Resilient infrastructure and maintenance & 4.4 & 0.99 & 1 & 11 \\
\hline Adequate livelihood & 4.4 & 0.88 & 1 & 12 \\
\hline Community engagement and empowerment & 4.35 & 0.75 & 1 & 13 \\
\hline Inter-community relationships & 4.35 & 0.67 & 1 & 14 \\
\hline Disaster management centres & 4.3 & 0.86 & 1 & 15 \\
\hline Equal distribution of the responsibility & 4.3 & 0.8 & 1 & 16 \\
\hline Educational status & 4.2 & 0.77 & 1 & 17 \\
\hline Exhibition programmes & 4.15 & 0.75 & 1 & 18 \\
\hline Role of faith-based organisation & 4.15 & 0.75 & 1 & 19 \\
\hline Access to credit & 4.1 & 0.79 & 1 & 20 \\
\hline
\end{tabular}


Table 6

Total community resilience indicators reaching consensus in Delphi two and three

\begin{tabular}{|lllllll|}
\hline Elements & Delphi two & \% & $\begin{array}{l}\text { Delphi } \\
\text { three }\end{array}$ & & \\
\cline { 2 - 5 } & $\begin{array}{l}\text { Total } \\
\text { indicators }\end{array}$ & $\begin{array}{l}\text { Consensus of } \\
\text { indicators }\end{array}$ & $\%$ & $\begin{array}{l}\text { Total } \\
\text { indicators }\end{array}$ & $\begin{array}{l}\text { Consensus of } \\
\text { indicators }\end{array}$ & $\%$ \\
\hline $\begin{array}{l}\text { Training and } \\
\text { awareness }\end{array}$ & 2 & 2 & 100 & 3 & 3 & 100 \\
$\begin{array}{l}\text { Health and } \\
\text { fatality }\end{array}$ & 1 & 0 & 0 & 1 & 1 & 100 \\
\hline Environmental & 2 & 1 & 50 & 2 & 2 & 100 \\
\hline Infrastructural & 3 & 2 & 67 & 3 & 3 & 100 \\
\hline Institutional & 3 & 2 & 67 & 4 & 4 & 100 \\
\hline Social & 2 & 1 & 50 & 2 & 2 & 100 \\
\hline Economic & 3 & 1 & 33 & 4 & 4 & 100 \\
\hline Demographic & 1 & 1 & 100 & 1 & 1 & 100 \\
\hline
\end{tabular}

\subsection{Overall Ranking of all the Community Resilience Elements and their Indicators}

As shown from the Delphi results, consensus among the experts on the indicators for measuring community resilience to climate change were established (Table 6). Table 7 shows the consensus from the third and final round of Delphi, with a weighted average ranging from 4.1 to 4.85 . Also, the grouped weighted average based on categorising the indicators under the elements were 4.2 to 4.75 . The standard deviation is $<1$ on each of the indicators ranging from 0.31 to 0.99 . Likewise, the IQR was less and equal to 1 on all the community resilience indicators. The final ranking of the community resilience elements and their indicators shows training and awareness as the first and demographic as the least (Table 7). 
Table 7

Community resilience elements and indicators rating results

\begin{tabular}{|c|c|c|c|c|c|c|}
\hline Elements & Community Resilience Indicators & WA & SD & IQR & $\begin{array}{l}\text { Grouped } \\
\text { WA }\end{array}$ & Rank \\
\hline \multirow{3}{*}{$\begin{array}{l}\text { Training and } \\
\text { awareness }\end{array}$} & Learning and awareness & 4.9 & 0.31 & 0 & \multirow[t]{3}{*}{4.75} & \multirow[t]{3}{*}{1} \\
\hline & $\begin{array}{l}\text { Communicating information in local } \\
\text { languages }\end{array}$ & 4.85 & 0.37 & 0 & & \\
\hline & $\begin{array}{l}\text { Adequate resource monitoring and } \\
\text { feedback mechanisms }\end{array}$ & 4.15 & 0.88 & 1 & & \\
\hline $\begin{array}{l}\text { Health and } \\
\text { fatality }\end{array}$ & $\begin{array}{l}\text { Access to healthcare assistance and } \\
\text { facilities }\end{array}$ & 4.65 & 0.59 & 1 & 4.65 & 2 \\
\hline \multirow[t]{2}{*}{ Environmental } & Sustainable agricultural practices & 4.7 & 0.47 & 1 & \multirow[t]{2}{*}{4.57} & \multirow[t]{2}{*}{3} \\
\hline & Renewable energy & 4.45 & 0.94 & 1 & & \\
\hline \multirow[t]{3}{*}{ Infrastructural } & $\begin{array}{l}\text { Resilient infrastructure and } \\
\text { maintenance }\end{array}$ & 4.4 & 0.99 & 1 & \multirow[t]{3}{*}{4.4} & \multirow[t]{3}{*}{4} \\
\hline & Disaster management centres & 4.3 & 0.86 & 1 & & \\
\hline & $\begin{array}{l}\text { Adequate domestic and industrial } \\
\text { waste facilities }\end{array}$ & 4.5 & 0.69 & 1 & & \\
\hline \multirow[t]{4}{*}{ Institutional } & Equal distribution of the responsibility & 4.3 & 0.8 & 1 & \multirow[t]{4}{*}{4.37} & \multirow[t]{4}{*}{5} \\
\hline & Synergy and harmonisation of policy & 4.55 & 0.6 & 1 & & \\
\hline & $\begin{array}{l}\text { Enforcement of good land use } \\
\text { planning }\end{array}$ & 4.5 & 0.69 & 1 & & \\
\hline & Role of faith-based organisation & 4.15 & 0.75 & 1 & & \\
\hline \multirow[t]{2}{*}{ Social } & $\begin{array}{l}\text { Community engagement and } \\
\text { empowerment }\end{array}$ & 4.35 & 0.75 & 1 & \multirow[t]{2}{*}{4.35} & \multirow[t]{2}{*}{6} \\
\hline & Inter-community relationships & 4.35 & 0.67 & 1 & & \\
\hline \multirow[t]{4}{*}{ Economic } & Adequate livelihood & 4.4 & 0.88 & 1 & \multirow[t]{4}{*}{4.28} & \multirow[t]{4}{*}{7} \\
\hline & Exhibition programmes & 4.15 & 0.75 & 1 & & \\
\hline & Access to credit & 4.1 & 0.79 & 1 & & \\
\hline & Ecological funding & 4.5 & 0.76 & 1 & & \\
\hline Demographic & Educational status & 4.2 & 0.77 & 1 & 4.2 & 8 \\
\hline
\end{tabular}

The presence of community resilience indicators can actively enhance climate change preparedness and recovery (Plough et al. 2013; Steiner et al. 2016). Also, strengthening community resilience to climate 
change is critical in the face of uncertainty and the expected increase of climate change impact in the future (Ziyath et al. 2013). The measurement of community resilience indicators is not meant to be used to compare one community against another. Preferably, it should be used as a relative measure within each community to identify better where investments and resources could be effectively applied to address their challenges. As such, this research identified elements and indicators relevant to developing countries that can be prioritised for measuring the effectiveness of current policies designed to support community resilience to climate change.

Figure 1 shows the final eight elements from Table 7, and their associated indicators as developed in the current study for measuring community resilience to climate change, with 20 indicators identified by the experts and five transformative capacity indicators identified from the literature (Ogah, 2021). There are several similarities and differences between the current research and previous ones where, for example, community resilience elements from our work are in-line with that by Cutter et al. (2014), Alshehri et al. (2015) and Qin et al. (2017). Specifically, coping capacity is defined as consisting of seven elements (social, economic, infrastructural, institutional, demographic, environmental and health and fatality) that drive the resources, the capacity to prepare, absorb and recover from an event. The coping capacity indicators focus on short term strategies after a climate event. However, to improve community resilience, it is not simply about the short-term response strategies but nurturing and fostering stakeholders to engage in positive and sustainable strategies that build on the three capacities. The definition of adaptive capacity consists of six elements (training and awareness, social, economic, institutional, infrastructural, and environmental) that drive the processes that aid changes through learning, reorganisation and adaptation of communities to plan and respond to climate event.

Transformative capacity includes two elements (institutional and infrastructural) that involve changes in the deep structures that cause vulnerability and risk (Table 8). Transformative capacity also includes the institutional mechanism, regulations, infrastructure and social protective mechanism that create enabling environment for change. The main difference between the review indicators (Ogah, 2021) and the indicators identified by the experts is that the indicators from the review are more generalised as identified from different publications, context and scale. In contrast, the experts in the current study identified the indicators that are needed for the communities in developing countries and indicators that should be prioritised due to inadequate funding in the implementation of policies. 
Table 8

Linking the capacities, elements and indicators of community resilience

\begin{tabular}{|c|c|c|}
\hline Capacities & Elements & Expert indicators \\
\hline \multirow[t]{4}{*}{ Coping capacity } & Social & Inter-community relationships \\
\hline & Demographic & Educational attainment \\
\hline & Institutional & Role of faith base organisation \\
\hline & Health and fatality & Access to health assistance and facilities \\
\hline \multirow[t]{16}{*}{ Adaptive capacity } & Social & Community engagement \\
\hline & \multirow[t]{4}{*}{ Economic } & Adequate livelihood \\
\hline & & Exhibition programmes \\
\hline & & Access to credit \\
\hline & & Ecological funding \\
\hline & \multirow[t]{3}{*}{ Infrastructural } & Resilient infrastructure and maintenance \\
\hline & & Adequate domestic and industrial waste facilities \\
\hline & & Disaster management centre \\
\hline & \multirow[t]{3}{*}{ Institutional } & Enforcement of good land use planning \\
\hline & & Equal distribution of responsibility \\
\hline & & Synergy and harmonisation of policy \\
\hline & \multirow{3}{*}{$\begin{array}{l}\text { Training and } \\
\text { awareness }\end{array}$} & Learning and awareness \\
\hline & & Communicating information in local languages \\
\hline & & $\begin{array}{l}\text { Adequate resource monitoring and feedback } \\
\text { mechanisms }\end{array}$ \\
\hline & \multirow[t]{2}{*}{ Environmental } & Sustainable agricultural practices \\
\hline & & Renewable energy \\
\hline \multirow{5}{*}{$\begin{array}{l}\text { Transformative } \\
\text { capacity }\end{array}$} & \multirow[t]{2}{*}{ Institutional } & Mitigation plan \\
\hline & & Accident planning \\
\hline & \multirow[t]{3}{*}{ Infrastructural } & Access to water \\
\hline & & Access to electricity \\
\hline & & Transportation \\
\hline
\end{tabular}




\subsubsection{Training and Awareness Element}

Training and awareness is one of the most important elements to measure community resilience to climate change in this study. The element was ranked first and emphasised three indicators that contribute to measuring resilience level. The learning and awareness indicators measure the number of awareness campaigns, training programmes and local skills available in communities. Adequate resource monitoring and feedback mechanisms were measured by the number of resources and projects that are monitored, and the number of stakeholders that have access to this information and provide feedback. Furthermore, communicating information in local languages, i.e. the number of agencies that give out information in local languages for communities to be able to prepare for and overcome any sudden occurrence, is an essential indicator that measures community resilience in the face of climate change in developing countries. According to Channa and Ahmed (2010), the availability of information and communication during and after an event is very important. The number of awareness campaigns, training programmes and social skills available in communities have positively contributed to developing community resilience (Norris, 2008). The community as a whole should know about climate change hazards and the effects to which they are exposed, as well as how to plan, prepare, cope and adapt. Training and awareness provide various techniques or knowledge aspects that could be applied to actions to deal with any event.

\subsubsection{Health and Fatality Element}

For communities to be able to meet their needs and achieve better living conditions, the health and fatality indicator is very significant. It improves sanitation standards, health assistance and facilities, thereby ensuring the health-related safety and general well-being of community members (Orencio and Fuji, 2013; Alshehri et al. 2015; Alam et al. 2018). The overall resilience of a community can rest on the extent to which community members lead healthy lifestyles, have access to hospitals and doctors and are aware of the community's health-related functional needs. Activities such as sanitation, infection control and awareness, nutritional status and awareness, and health insurance, are indicators that help to improve well-being (Cutter et al. 2014; Alshehri et al. 2015; Ahmed et al. 2016). In this study, the health and fatality indicators such as access to healthcare assistance and facilities, which are measured by the percentage of community members with access to doctors, nurses, clinics and hospitals, serve as community resilience indicators that help to manage climate change in developing countries. Under extreme conditions, the ability or capacity of trained health workers, and the availability of health centres and resources to effectively respond to these events, is vital. Health and fatality element and its related indicators have largely been incorporated into social indicators in most studies (Cutter et al. 2014). However, in this study, it is a standalone element that is key to measuring community resilience in communities.

\subsubsection{Environmental Element}

By improving green spaces, quality of natural resources and protecting biodiversity, environmental indicators activities can have direct implications for local climate change (Mavhura, 2017). They are, 
therefore, useful community resilience indicators to manage climate change in developing countries. The identified environmental indicators are renewable energy sources and sustainable agricultural practices. These are measured by the percentage of energy demand serviced by renewable energy sources, and the percentage of people involved in agricultural practices that mitigate the impacts of climate change.

\subsubsection{Infrastructural Element}

Infrastructure is a crucial area for achieving community resilience (Ainuddin and Routray, 2012; Feldmeyer et al. 2019). The ability of these infrastructures to withstand the shock posed by climate change represents the strength of the physical capital of the community. This research reveals that infrastructures are among the community resilience elements identified by experts to manage climate change. Specific indicators include resilient infrastructure and maintenance, which are measured by the percentage of buildings with building codes, sewers, and drains to handle excess water to prevent flooding, and adequate domestic and industrial waste facilities. They are measured also by the number and capacity of waste facilities available, disaster management centres, and the number of recovery centres relative to community size. The availability of physical capital, such as drains, sewers, waste facilities and recovery centres, is necessary for supporting various stages of community resilience starting from climate change mitigation to adaptation (Cutter et al. 2014; Ahmed et al. 2016), thus protecting the community from climate change repercussions. From a different perspective, Ahmed et al. (2016) stated that the development of resilient infrastructure and technologies such as barriers built for floods - seawalls and breakwaters - are substantial infrastructural barriers that are used to protect communities from flood or sea-level rise. However, Cai et al. (2016) observed that the existence of construction codes solely could not contribute to reducing the impact of climate change effect. It can, therefore, be implied that building codes have to be supported with other resilient infrastructures. They also claimed that high-density buildings and roads on lowlands would make communities more vulnerable to flood. However, infrastructural indicators are expensive to strengthen; therefore, the resilience of the physical capital of the community largely depends on the economic health of that community.

\subsubsection{Institutional Element}

Institutional element influences the capacities of a community to adapt to climate change events and is responsible for initiating and facilitating transformational processes to build resilience (Chung, 2017). This covers the arrangements and experience relating to the management of climate change impact that exists in a community (Feldmeyer et al. 2019). It is based on the development and maintenance of structured involvement and various networks that can contribute to the requirements of the community in planning and preparedness (Irwin et al. 2016). Our study shows that there is a general consensus on the institutional indicators, namely: Enforcement of good land use planning, i.e. implementation of plans on land use that are designed to mitigate the impacts of climate change; Equal distribution of the responsibility for the implementation of policy between the different sectors involved in the policy process; Synergy and harmonisation of policy, i.e. a common standard in regulations in different sectors, constituting of indicators to measure community resilience to manage climate change in developing 
countries; The role of faith-based organisations i.e. number of faith-based organisations involved in supporting the communities. Every community needs inclusive governance such as government, businesses, organisations and communities in making decisions, coordinating activities and integrated development planning.

Equal distribution of responsibility across government and non-governmental agencies helps to create the opportunity for development and fast track policy activities (Bulkeley, 2010). However, the key to this level of partnership for equal distribution of responsibility with other organisations is the level of coordination and organisation within the community itself (United Nations, 2012). Synergy and harmonisation of policy provide the ability, and builds capacity, to make decisions and implement strategies across a range of responsibilities and services (Tanner et al. 2009). Also, due to the crosscutting nature of climate change governance, most government departments and agencies are often not able to implement policies that need to address climate change problems. Thus, a good synergy and harmonisation of policy will help to bolster community resilience. Furthermore, the role of faith-based organisations can significantly engage and empower community members to develop resilience (Niaz, 2006). This is important since most developing countries are multi-religious, with high numbers of religious faith-based groups. Overall, the indicators within the institutional element reflect that top-down to bottom-up approaches should be adopted in creating linkages and planning and preparedness to enable communities to cope and recover from an event (Joerin et al. 2012).

\subsubsection{Social Element}

The social element consists of the activities and processes which build collaboration between individuals within and outside the community (Cutter, 2010; 2014; Aldrich and Meyer, 2014; Kim et al. 2017). Social indicators support fast and reliable relationships that constitute a network that can help release ideas, lessen losses and improve the community's self-reliability. In the current study there is a consensus amongst the experts that social indicators like community engagement and empowerment are closely linked. That is, the percentage of people involved in community activities and inter-community relationships or working relationships between two or more communities, are among the community resilience indicators that help to manage climate change in the context of Nigeria. Community engagement and empowerment programmes would not only encourage community members to become responsible but also knowledgeable and aware of their community's socio-economic and ecological status (Cutter et al. 2014; Forest and Milliken, 2018). Therefore, community engagement and empowerment processes are significant acts for measuring community resilience. Furthermore, intercommunity relationship is generally based upon the relatability among the people living under similar conditions, providing social supports and assistance, especially in case of emergencies (Amundsen, 2012). The more people are involved in community services, the easier it is for the community to adapt to climate change (Khalili et al. 2015). Also, cooperation between two or more communities on climate challenges helps build more robust and broader community resilience and faster recovery following a climate-induced disaster (Amundsen, 2012; Smith, 2012; Islam and Walkerden, 2017). These measures foster bonding, bridging, linkages and connectedness among the community members, which is very 
important during a climate event (Aldrich and Meyer, 2014). Thus, the larger the membership in the community, the higher the collective action to support community resilience to climate change.

\subsubsection{Economic Element}

The economic element plays a vital role in the empowerment of communities to become resilient to climate change (Bach, 2015; Kim and Marcuiller, 2016). This element is assessed from the household level to the entire community and includes community finances for various purposes on different levels that can support the community's goal. Also, there is a consensus on the economic indicators, and they are a significant component of community resilience to manage climate change. These include: (i) Adequate livelihood, i.e. the percentage of people living below the poverty line; (ii) Access to credit, measured by the percentage of people with access to credit facilities; (iii) Ecological funding, i.e. the percentage of annual spending from the government for climate change mitigation and adaptation projects; and (iv) Exhibition programmes, i.e. a number of local exhibition programmes to showcase community-based products. One primary reason why people are vulnerable to climate change is related to their economic status (Lo et al. 2015). People who are limited in income or live below the poverty line will find it challenging to put up adaptive measures in place against climate change (Ahmed et al. 2016; Quasim et al. 2016). Furthermore, Qin et al. (2017) posited that improved livelihood of an individual as an intrinsic part of the community would influence the community resilience as its sufficiency would absorb the climate change-related repercussions and accelerate the adoption process. It is assumed that a diversified community livelihood makes the community more resilient and can improve their stability (Norris et al. 2008; Wilson, 2013; Ashkenazy et al. 2017). Hence, the higher the level of finances, the greater the ability of households and community to absorb the impacts of climate change.

Access to credit was considered a significant resource for enhancing the financial ability of communities to adapt (Feldmeyer et al. 2019). Furthermore, funding of ecological projects is necessary for policy activities to succeed, and this responsibility needs to be shared by all those who have a stake (United Nations, 2012). Many developing nations do not have sufficient budgets to support policy activities and cannot provide subsidies or incentives for sustainable plans and preparedness. Thus, these indicators are considered necessary in measuring community resilience to climate change. Also, a community can have education, training and infrastructural facilities; however, if its economy is weak and affecting livelihoods, then all other indicators will not succeed (Norris et al. 2008).

\subsubsection{Demographic Element}

Demographic element is an integral part of community resilience (Akamani, 2012; Bene et al. 2017). It plays a significant role in collecting the attributes of the community, which is further used in measuring efficiency in the implementation of policy actions. In this research, the demographic element focused on educational status, i.e. the percentage of the population with school leaving certificate is an identified factor that supports community resilience to climate change. There was a consensus among all the experts that a well-informed individual has the knowledge and skills to put adaptive measures in place to enable community resilience. According to Ainuddin and Routray (2012), educational status gives an 
abstract idea of how educated and informed the people are towards the knowledge transfer and skills that could be useful during emergencies. Thus, the higher the ratio of the educated to uneducated people in a community, the better placed the community is to cope with climate change. In addition, improving and investing in education will save many lives and enhance community resilience (United Nations, 2012). This element was incorporated into the social element in other studies (Qasim et al. 2016; Qin et al. 2017), contrasting our study, where demography is a separate element with its respective indicators to measure community resilience to climate change.

\section{Discussion}

The Delphi round one identified how community resilience is defined by experts, relative to the literature, and a clear set of elements and their indicators to measure community resilience to climate change. While the concept of community resilience is complex (Bergstrand et al. 2014; Patel et al. 2017), the current findings indicate that the experts had a clear understanding of the concept. The definitions they provided were on two generic terms: coping capacity and adaptive capacity. Importantly, community resilience as adaptive capacity was defined by most of the expert group. The conceptualisation of community resilience as adaptability is in agreement with other studies (Norris et al. 2008; Ferro-Azcona et al. 2019). The critical aspect of community resilience as adaptive capacity is accepting that change is ongoing and, consequently, highly unpredictable. As a result, adaptive capacity is about flexibility and the ability to make constant changes through the continuous process of adjusting, learning and innovating (Henly-Shepard et al. 2015; Sandanam et al. 2018). This finding is slightly different from our review finding (Ogah 2021), as most of the 1036 analysed publications defined community resilience as the combination of coping and adaptive capacity. Understanding the linkages between 'coping capacity' and 'adaptive capacity' of community resilience is critical to furthering community capacity to respond to both short- and long-term change. Both approaches are equally important considerations for community resilience and a joined holistic approach with the definition of community resilience more likely to be functional in practice. Critically, as identified during this study, a definition of community resilience focusing on stability could be designated as 'coping capacity' and would demand broader, bottom-up processes of response, not the 'top-down, command and control' that focuses on continued changes.

One of our key findings is that community resilience was not defined in terms of transformative capacity by the experts. The understanding of community resilience in terms of transformative capacity as a concept is very important as it would give direction and provide a long-term structure for preparedness for communities to reach a sustainable future (Chung, 2017; Choko et al. 2019). Society needs to move towards transformative capacity that involves robust reflective learning in the face of climate change (Otoara-Ha'apio et al. 2018). Transformative understandings of community resilience offer more significant potential for creating shared action and 'future-proofing' communities, through providing a long-term structure for community preparedness and reaching their goal. Due to continued risk arising from climate change, communities can benefit from a more sustainable planning which will lead to transformative changes by increasing resilience in communities. 
The experts at the regional level stated that community engagement and participation was not sufficient due to lack of capacity building, as people are not really aware of the impact of climate change and policies to be implemented in their communities while some are not concerned about what is actually happening. However, the national level experts felt that community members need to own the process before the policy impact can be felt. One of them indicated that ' when plans are put in place, community members do not follow it through $(\mathrm{A})$. This is also a significant problem with implementation of activities where community members do not cooperate with government officials if they do not see any financial gains from the required work. According to Markantoni et al. (2019), community engagement and participation is vital for policy strategy to be successful to improve resilience in communities. In order to encourage community participation by supporting their empowerment, the government should understand the status of local needs and level of awareness before designing and implementing policies. This statement was supported by Shortall (2008) who highlighted that there is a need for inclusive engagement that ensures the participation of communities.

The extent to which communities can offer resistance, or recover and adapt to changes, is based on the different capacities which are part of that specific community that is stressed (Twigger-Ross et al. 2016). Respective communities need to understand their capacities and vulnerabilities for the development of community resilience to climate change. In this study, the experts identified 20 indicators that are categorised into eight community resilience elements (infrastructure, training and awareness, environmental, social, economic, institutional, demographic and health and fatality). These measurable indicators are necessary precursors in the process of communities becoming resilient in the face of climate change.

This study identified an indicator that was not recognised in the published literature. Synergy and harmonisation of policy helps in the interaction between various institutional arrangements or strategies in the planning and implementation of adaptation and mitigation policies. This indicator promotes joint efforts in building capacity, avoiding duplication, broadening knowledge base, encouraging cooperation, providing opportunities and sharing experiences (UNFCCC, 2015). Also, the most mentioned elements were infrastructural and training and awareness. This is different from other literature, where the social and economic elements were mostly addressed. In the context of developing countries like Nigeria, these elements (infrastructural and training and awareness) are given more priority as they are the core areas where resilience needs to be built. This is due to the countries' geographical area, land characteristics, coastal locations, high temperatures, large populations and limited financial, technology and adaptation capacities to adapt to climate change (IPCC, 2014; Ogbuabor and Egwuchukwu, 2017). Likewise, the health and fatality element was the least identified by most literature (Alshehiri, et al. 2015; Alam et al. 2018) and the experts. According to Plough et al. (2013), healthcare is an integral part of community resilience and the backbone of medical responses to an event. Health and fatality deals with access to healthcare services at the time of and after, a climate change event. Apart to hospital setup, it focuses also on staff, services and facilities that are to be used by general members of the public, including those with different disabilities and special needs (Alshehri et al. 2015; Ahmed et al. 2016). Besides, this element encompasses the activities related to the preventive measures for various epidemics that are 
common after climate change events, mostly in developing countries. The poor in developing countries who have limited access to healthcare and poor resistance (Ludwig et al., 2007) feel climate change impacts on health more. Encouraging activities to improve this element can enhance the health status of the community members, reassure their lives and increase the number of participants that are fit to take part in climate change activities.

Due to the increased number of participants as a result of improved wellbeing, the cost of community resilience activities can be potentially reduced. Some of the activities to support this element would involve seeking help from the surrounding communities, which would lead to inter-community bonding. This would improve their relationship further, including business activities, and contribute positively to other elements. As a result of such deep interlinkages among the elements, a priority order cannot be assumed without understanding the needs of the communities. Hence it is more appropriate to use the phrase, 'relative prioritisation with respect to the targeted community'. Generally, prioritisation needs two criteria to be considered before analysis: the importance; and the need. While the measurement of community resilience is challenging and potentially constraining (Sharifi, 2016), the community resilience elements and indicators identified here are grounded and coherent for the broader application of community resilience within policy planning processes. Likewise, this could form a basis for the development of policy prioritisation guidance around community resilience applications for developing countries.

\section{Conclusion}

Through the GDM process, this study established a set of elements and indicators that represent a consensus-based community resilience capability to reduce the impacts of climate change. Specifically, eight community resilience elements and 25 indicators were identified as integral yet versatile in helping decision-makers to plan towards enhancing community resilience to climate change effectively. Given paucity of funds for policy implementation, the indicators identified would help in prioritising actions based on the identified gaps in a given community. To this end, this study defined community resilience as a process of stages that communities need to go through to become resilient to climate change. These begin with coping with climate change (short-term) then progress towards adaptation to climate change (medium-term) with the final stage being transformation in the face of climate change (long-term). The elements and their indicators provide guidance to enable policy makers plan in climate change readiness for communities to become resilient. Finally, the study provided a methodology by which consensus between experts, on how competing issues may be prioritised to improve community resilience in developing countries, can be achieved. A well-developed and well-resourced flexible community planning process represents a fundamental basis for future change to inform policy activities that support community resilience at the local, regional and national level.

\section{References}


1. Abramson D M, Grattan L M, Mayer B, Colten C E, Arosemena F A, Bedimo-Rung A, Lichtveld M (2015) The resilience activation framework: a conceptual model of how access to social resources promotes adaptation and rapid recovery in post-disaster settings. The Journal of Behavioural Health Services and Research. 42(1), pp. 42-57.

2. Ahmed B, Kelman I, Fehr H K, Saha M (2016) Community resilience to cyclone disasters in coastal Bangladesh. Sustainability 8(805), pp. 1-29.

3. Ainuddin S and Routray J K (2012) Earthquake hazards and community resilience in Baluchistan. Natural Hazards. 63, pp. 909-937.

4. Akamani K (2012) A community resilience model for understanding and assessing the sustainability of forest-dependent communities. Human Ecology Review. 19(2), pp. 25-36.

5. Akanwa A O and Joe-lkechebelu N (2018) The Developing World's Contribution to Global Warming and the Resulting Consequences of Climate Change in These Regions: A Nigerian Case Study. Global Warming and Climate Change. pp. 1-13.

6. Alam G M M, Alam K, Mushtaq S, Filho W L (2018) How do climate change and associated hazards impact on the resilience of riparian rural communities in Bangladesh? Policy implications for livelihood development. Environmental Science and Policy. 84, pp. 7-18

7. Aldrich D P and Meyer M (2014) Social capital and community resilience. American Behavioral Scientist. 59(2), pp. 254-269.

8. Alshehri S, Rezgui A, Li Y (2015) Delphi-based consensus study into a framework of community resilience to disaster. Natural Hazards. 75, pp. 2221-2245.

9. Amundsen $\mathrm{H}$ (2012) Illusions of resilience? An analysis of community responses to change in northern Norway. Ecology and Society. 17(4), pp. 1-14.

10. Ashkenazy A, Chebach T C, Knickel K, Peter S, Horowitz B, Offenbach R (2017) Operationalising resilience in farms and rural regions - Findings from fourteen case studies. Journal of Rural Studies. pp. 1-11.

11. Asun A R, Rdz-Navarro K, Alvarado M J (2016) Developing multidimensional Likert scales using item factors analysis: The case of four-point items. Sociological Methods and Research, 45(1), pp. 109133.

12. Bach R (2015) Strategies for supporting community resilience: Multinational experiences. In Bach, R. L., Kaufman, D. J., Dahns, F. What works to support community resilience? Multinational Resilience Policy Group, Swedish Defence University, Elanders Sverige AB, Stockholm.

13. Bailie J L (2011) Effective online instructional competencies as perceived by online university faculty and students: A sequel study. Journal of Online Learning and Teaching, 7, pp. 82-89.

14. Barua A, Katyaini S, Mili B and Gooch P (2014) Climate change and poverty: Building resilience of rural mountain communities in South Sikkim, Eastern Himalaya, India. Regional Environmental Change, 14(1), pp. 267-280.

15. Béné C, Wood R G, Newsham A, Davies M (2012) Resilience: New Utopia or New Tyranny? Reflection about the potentials and limits of the concept of resilience in relation to vulnerability reduction 
programmes. IDS Working Papers, 405, pp.1-61.

16. Béné C, Mehta L, McGranahan G, Cannon T, Gupte J, Tanner T (2017) Resilience as a policy narrative: potentials and limits in the context of urban planning. Climate and Development, 10(2), pp. 116-133.

17. Berbes-Blazquez M, Mitchell C L, Burch S L, Wandel J (2017) Understanding climate change and resilience: assessing strengths and opportunities for adaptation in the Global South. Climate Change, pp. 1-16.

18. Bergstrand K, Mayer B, Brumback B, Zhang Y (2015) Assessing the relationship between social vulnerability and community resilience to hazards. Social Indicators Research, 122(2), pp. 391-409.

19. Bryman A (2016) Social research methods. Oxford, Oxford University Press.

20. Bulkeley H (2010) Cities and the governing of climate change. Annual Review of Environment and Recourses, 35(2), pp. 229-253.

21. Cai H, Lam N S, Zou L, Qiang Y, Li K (2016) Assessing community resilience to coastal hazards in the Lower Mississippi River Basin. Water, 8(2), pp. 1-18.

22. Campos I, Guerra J, Gomes J F, Schmidt L, Alves F, Vizinho A, Lopes G P (2017) Understanding climate change policy and action in Portuguese municipalities: A survey. Land Use Policy, 62, pp. 6878.

23. Channa M I and Ahmed K M (2010) Emergency response communications and associated Security Challenges. pp. 1-14.

24. Charmaz K (2014) Constructing Grounded Theory. SAGE.

25. Choko O P, Olabisi L S, Onyeneke R U, Chiemela S N, Liverpool-Tasie L S O, Rivers L (2019) A resilience approach to community-scale climate adaptation. Sustainability, 11, pp. 1-16.

26. Chung T F T (2017) Transformational processes for community-focused adaptation and social change: a synthesis. Climate and Development, 9(1), pp. 5-21.

27. Cloke P, Cook I, Crang P, Goodwin M A, Painter J, Philo C (2004) Practicing human geography. London: SAGE Publications.

28. Constas M, Frankenberger T, Hoddinott J (2014) Resilience measurement principles: Towards an agenda for measurement design. Resilience Measurement Technical Working Group Technical Series. Rome: FSIN (FAO/WFP).

29. Cutter S L (2016) The landscape of disaster resilience indicators in the USA. Natural Hazards, 80(2), pp. 741-758.

30. Cutter S L (2020) Community resilience, natural hazards, and climate change: Is the present a prologue to the future. Norsk Geografisk Tidsskrift - Norwegian Journal of Geography, 74(3), pp. 200208.

31. Cutter S L, Ash K D, Emrich C T (2014) The geographies of community disaster resilience. Global Environmental Change, 29, pp. 65-77.

32. Cutter S L, Barnes M L, Berry C, Burton E, Evans E, Tate E, Webb J (2008) A place- based model for understanding community resilience to natural disasters. Global Environmental Change, 18(4), pp. 
598-606.

33. Cutter S L, Burton C G, Emrich C T (2010) Disaster resilience indicators for benchmarking baseline conditions. Journal of Homeland Security and Emergency Management, 7(1).

34. Diamond I R, Grant R C, Feldman B M (2014) Defining consensus: a systematic review recommends methodologic criteria for reporting of Delphi studies. Journal of Clinical Epidemiology, 67(4), pp. 401409.

35. Donohoe H M (2011) Defining culturally sensitive ecotourism: A Delphi consensus. Current Issues in Tourism, pp. 27-45.

36. Doorn N (2017) Resilience indicators: opportunities for including distributive justice concerns in disaster management. Journal of risk Research, 20(6), pp. 711-731.

37. Engle N, De Bremond A, Malone E, Moss R (2013) Towards a resilient indicator framework for making climate change adaptation decisions. Mitigation Adaptation Strategy Global Change, pp. 1-18.

38. Feldmeyer D, Wilden D, Kind C, Kaiser T, Goldschmidt R, Diller C, Birkmann J (2019) Indicators for monitoring urban climate change resilience and adaptation. Sustainability, 11, pp. 1-17.

39. Ferro-Azcona H, Espinoza-Tenorio A, Calderon-Contreras R, Ramenzoni V G, Pais M L M G, MesaJurado M A (2019) Adaptive capacity and social-ecological resilience of coastal areas: a systematic review. Ocean and Coastal Management, 173, pp. 36-51.

40. Forrest S and Milliken C (2018) Building resilience to disaster: From advice to action. European Review, pp. 1-10.

41. Giannarou L and Zervas E (2014) Using Delphi technique to build consensus in practice. International Journal of Business Science and Applied Management, 9(2), pp. 65-82.

42. Gillard R, Gouldson A, Paavola J, Van Alstine J (2017) Can national policy blockages accelerate the development of polycentric governance? Evidence from climate change policy in the United Kingdom. Global Environmental Change, 45, pp.174-182.

43. Goldman K, Gross P, Heeren C, Herman G, Kaczmarczyk L, Loui M C, Zilles C (2008) Identifying important and difficult concepts in introductory computing courses using a Delphi process. ACM SIGCSE Bulletin, 40, pp. 256-260.

44. Greatorex J and Dexter T (2000) An accessible analytical approach for investigating what happens between the rounds of a Delphi study. Journal of Advanced Nursing, 32, pp.1016-1024.

45. Goula A (2013) The organizational culture of public hospital: Factors of transition from the bureaucratic to a new model of management. PhD Thesis, Panteion University of Political and Social Sciences.

46. Hasson F, Keeney S, McKenna H (2000) Research guidelines for the Delphi survey technique. Journal of Advanced Nursing, 32(4), pp. 1008-1015.

47. Henly-Shepard S, Anderson C, Burnett K, Cox L J, Kittinger J N, Ka`aumoana M (2015) Quantifying household social resilience: a place-based approach in a rapidly transforming community. Natural Hazards, 75(1), pp. 343-363. 
48. Howard K (2018) Emergence of a new method: The Grounded Delphi Method. Library and Information Research, 42(126), pp. 5-31.

49. IPCC (2007) Adaptation and mitigation options. In (book section): Summary for Policymakers. In: Climate Change 2007: Synthesis Report. Contribution of Working Groups I, II and III to the Fourth Assessment Report of the Intergovernmental Panel on Climate Change (Core Writing Team, Pachauri R K and Reisinger A (eds.)). IPCC, Geneva, Switzerland. This version: IPCC website. Retrieved 02-082017.

50. IPCC (2014) Climate change 2014: Synthesis report. Contribution of working groups I, II and III to the fifth assessment report of the Intergovernmental Panel on Climate Change. [Core Writing Team, Pachauri R K and Meyer L A (Eds.)]. IPCC, Geneva, Switzerland: pp. 93-112.

51. Irwin S, Schardong A, Simonovic S P, Nirupama N (2016) ResilSIM-A decision support tool for estimating resilience of urban systems. Water, 8(377), pp. 1-25.

52. Islam R and Walkerden G (2017) Social networks and challenges in government disaster policies: A case study from Bangladesh. International Journal of Disaster Risk Reduction, 22, pp. 325-334.

53. Jacob D B and Cramer L A (2017) Applying information network analysis to fire-prone landscapes: Implications for community resilience. Ecology and Society, 22(1), pp. 1-20.

54. Joerin J, Shaw R, Takeuchi Y, Krishnamurthy R (2012) Assessing community resilience to climaterelated disasters in Chennai, India. International Journal of Disaster Risk Reduction, 1(1), pp. 44-54.

55. Khalili S, Harre M, Morley P (2015) A temporal framework of social resilience indicators of communities to flood, case studies: Wagga and Kempsey, NSW, Australia. International Journal of Disaster Risk Reduction, 13, pp. 248-254.

56. Kim H and Marcouiller D W (2016) Natural disaster response, community resilience, and economic capacity: a case study of coastal Florida. Society and Natural Resources, 52, pp. 1-17.

57. Kim C, Nakanishib H, Blackmanc D, Ben Freyensa D, Bensond A M (2017) The effect of social capital on community co-production: Towards community-oriented development in post-disaster recovery. Procedia Engineering 180, pp. 901 - 911.

58. Lo A Y, Xu B, Chan F K S, Su R (2015) Social capital and community preparation for urban flooding in China. Applied Geography, 64, pp. 1-11.

59. Ludwig F, Van Scheltinga C T, Verhagen J, Kruijt B, Van lerland E, Dellink R, De Bruin K, De Bruin K, Kabat P (2007) Climate change impacts on developing countries - EU accountability. Policy Department: Economic and Scientific Policy, DG Internal Policies, European Parliament. Westvest, Netherlands, pp 1-45.

60. Manyena B, Machingura F, O'Keefe P (2019) Disaster Resilience Integrated Framework for Transformation (DRIFT): A new approach to theorising and operationalising resilience. World Development, 123, pp. 1-30.

61. Markantoni M, Steiner A A, Meador J E (2019) Can community interventions change resilience in rural places? Community Development, 50(2), pp 238-255. 
62. Mavhura E (2017) Applying a systems-thinking approach to community resilience analysis using rural livelihoods: The case of Muzarabani district, Zimbabwe. International Journal of Disaster Risk Reduction, 25, pp. 248-258.

63. Mavhura E, Manyena S B, Collins A E, Manatsa D (2013) Indigenous knowledge, coping strategies and resilience to floods in Muzarabani, Zimbabwe. International Journal of Disaster Risk Reduction, 5, pp. 38-48.

64. Musa H D, Mo Yacob M R, Abdullah A M, Ishak M Y (2015) Delphi method of developing environmental well-being indicators for the evaluation of urban sustainability in Malaysia. Procedia Environmental Sciences, 30, pp. $244-249$.

65. Murphy M, Black N, Lamping D, McKee C, Sanderson C, Askham J, Marteau T (1998) Consensus development methods, and their use in clinical guideline development. Heath Technology Assessment, 2(3). Pp. 1-88.

66. Niaz U (2006) Role of faith and resilience in recovery from psycho-trauma. Pakistan Journal of Medical Sciences, 22, 204.

67. Norris F H, Stevens S P, Pfefferbaum B, Wyche K F, Pfefferbaum R L (2008) Community resilience as a metaphor, theory, set of capacities and strategy for disaster readiness. Community Psychology, 41, pp. 127-150.

68. Ogah A (2021) Climate change in Nigeria: Assessing policy and practice for community resilience. $\mathrm{PhD}$ thesis, Teesside University, Middlesbrough, United Kingdom.

69. Ogbuabor J E and Egwuchukwu E I (2017) The impact of climate change on the Nigerian Economy. International Journal of Energy Economics and Policy, 7(2), pp. 217-223.

70. Okoli C and Pawlowski S D (2004) The Delphi method as a research tool: An example, design considerations and applications. Information \& Management 42(1), pp. 15-29.

71. Orencio P M and Fujii M (2013) A localized disaster-resilience index to assess coastal communities based on an analytic hierarchy process (AHP). International Journal of Disaster Risk Reduction, 3 , pp. 62-75.

72. Otoara-Ha'apio M, Wairiu M, Gonzalez R, Morrison K (2018) Transformation of rural communities: Lessons from a local self-initiative for building resilience in Solomon Islands. Local Environment, 23(3), pp. 352-365.

73. Päivärinta T, Pekkola S, Moe C (2011) Grounding theory from Delphi studies, ICIS Proceedings, Thirty Second International Conference on Information Systems, Shanghai, Research Methods and Philosophy, pp. 1-14.

74. Patel S S, Rogers M B, Amlôt R, Rubin G J (2017) What Do We Mean by community resilience? A Systematic Literature Review of How It Is Defined in the Literature, PLoS currents, 9, pp. 1-36.

75. Pietrapertosa F, Khokhlov V, Salvia M, Cosmi C (2017) Climate change adaptation policies and plans: A survey in 11 South East European countries. Renewable and Sustainable Energy Reviews, pp. 1-10.

76. Plough A, Fielding J E, Chandra A, Williams M, Eisenman D, Wells K B, Law G Y, Fogleman S, Magaña A (2013) Building community disaster resilience: perspectives from a large urban county department 
of public health. American journal of public health, 103, pp. 1190-1197.

77. Proag V (2014) The concept of vulnerability and resilience. Procedia Economic and Finance, 18, pp. 369-376.

78. Qasim S, Qasim M, Shrestha R P, Khan A N, Tun K, Ashraf M (2016) Community resilience to flood hazards in Khyber Pukhthunkhwa province of Pakistan. International Journal of Disaster Risk Reduction, 18, pp. 100-106.

79. Qin W, Lin A, Fang J, Wang L and Li M (2017) Spatial and temporal evolution of community resilience to natural hazards in the coastal areas of China. Natural Hazards, 89(1), pp. 331-349.

80. Quinlan A E, Berbes-Blazquez, Haider M L J, Peterson G D, Allen C (2015) Measuring and assessing resilience: Broadening understanding through multiple disciplinary perspectives. Journal of Applied Ecology, 53, pp.677-687.

81. Rayens M K and Hahn E J (2000) Building consensus using the policy Delphi method. Policy, Politics and Nursing Practice, 1(4), pp. 308-315.

82. Sandanam A, Diedrich A, Gurney G, Richardson T (2018) Perceptions of cyclone preparedness: Assessing the role of individual adaptive capacity and social capital in the wet Tropical Australia. Sustainability, 10. pp. 1165.

83. Sharifi A (2016) A critical review of selected tools for assessing community resilience. Ecological Indicators,69, pp. 629-647.

84. Shortall S (2008) Are rural development programmes socially inclusive? Social inclusion, civic engagement, participation, and social capital: exploring the differences. Journal of Rural Studies, 24 pp. $450-457$.

85. Slade S C, Dionne C E, Underwood M, Buchbinder R (2014) Standardised method for reporting exercise programmes: protocol for a modified Delphi study. BMJ, 4(12), pp.

86. Steiner A, Woolvin M, Harwell L C, Buck KD (2016) Measuring community resilience: developing and applying a 'hybrid evaluation' approach. Community development Journal, pp. 1 -20.

87. Summers V, Smith L M, Harwell L C, Buck K D (2017) Conceptualizing holistic community resilience to climate events: Foundation for a climate resilience screening index. Geographical Health, 1, pp. 151-164.

88. Tambo J A (2016) Adaptation and resilience to climate change and variability in north-east Ghana. International Journal of Disaster Risk Reduction, 17, pp. 85-94.

89. Tanner T, Bahadur A, Moench M (2017) Challenges for resilience policy and practice. London: ODI.

90. Taherdoost H (2016) Sampling methods in research methodology; How to choose a sampling technique for research. International Journal of Academic Research in Management, 5, pp. 18-27.

91. Tolentino-Arévalo O M, Markantoni A, Espinoza-Tenorio A, Mesa-Jurado M A (2019) Drivers of adaptive capacity to climate change in coastal fishing communities of Tabasco, Mexico. in S. Salas, M. J. Barragán-Paladines, and R. Chuenpagdee, editors. 'Viability and sustainability of small-scale fisheries in Latin America and the Caribbean', Springer, Cham, Switzerland, pp. 125-147. 
92. Twigger-Ross C, Brooks K, Papadopoulou L, Orr P, Sadauskis R, Coke A, Simcock N, Stirling A, Walker $\mathrm{G}$ (2015) Community resilience to climate change: an evidence review. Technical Report. York: Joseph Rowntree Foundation, pp. 1-91.

93. Ullah S, Noman M, Rahimi M, Stanikzai A G, Ayub S, Din Z U, Emiliya H, Esmati S, Zahoor F, Khan S (2021) A comprehensive review of climate change impacts on water resources: A global perspective. IOSR Journal of Environmental Science, Toxicology and Food Technology, 15(3), pp. 43-48.

94. United Nations Framework Convention on Climate Change (UNFCCC). (2015) Synthesis report on the aggregate effect of the intended nationally determined contributions (FCCC/CP/2015/7).

95. Wilson G (2013) Community resilience, policy corridors and the policy challenge. Land Use Policy, 31, pp.298-310.

96. Wood R S, Hultquist A, Romsdahl R J (2014) An examination of local climate change policies in the great plains. Review of Policy Research, 31(6), pp. 529-554.

97. Ziyath A M, Teo M, Goonetilleke A (2013) Surrogate indicators for assessing community resilience. Proceedings of the International Conference on Building Resilience 2013: Individual, Institutional and Societal Coping Strategies to Address the Challenges Associated with Disaster Risk, September 1719, Ahungalla, Sri Lanka, pp. 1-11.

\section{Figures}





Figure 1

Proposed community resilience elements and indicators 